\title{
Blended learning in permanent education of nursing professionals on smoking cessation
}

\author{
Abordagem híbrida na educação permanente de profissionais \\ de enfermagem sobre cessação do tabagismo
}

Enfoque híbrido en la educación permanente de profesionales de enfermería sobre dejar de fumar

\section{Fernanda Guarilha Boni ${ }^{\mathrm{a}}$ Lyana Duarte Borba Da Silva ${ }^{\mathrm{b}}$ Jamila Ivanise Grigolob Solange Klockner Boaz ${ }^{\mathrm{c}}$ Ana Luísa Petersen Cogo ${ }^{\mathrm{a}, \mathrm{d}}$ Isabel Cristina Echera,e}

\section{How to cite this article:} Boni FG, Da Silva LDB, Grigolo Jl, Boaz SK, Echer IC. Blended learning in permanent education of nursing professionals on smoking cessation. Rev Gaúcha Enferm. 2021;42(spe):e20200183. doi: https://doi.org/10.1590/19831447.2021.20200183 aniversidade Federal do Rio Grande do Sul, (UFRGS), Escola de Enfermagem, Programa de Pós-Graduação em Enfermagem. Porto Alegre, Rio Grande do Sul, Brasil.

- Hospital de Clínicas de Porto Alegre (HCPA) Coordenadoria de Gestão de Pessoas, Serviço de Qualificação e Aperfeiçoamento Continuado. Porto Alegre, Rio Grande do Sul, Brasil.

c Hospital de Clínicas de Porto Alegre (HCPA), Servis de Enfermagem Ambulatorial. Porto Alegre, Rio Grande do Sul, Brasil.

Hospital de Clínicas de Porto Alegre (HCPA), Serviço de Educação em Enfermagem. Porto Alegre, Rio Grande do Sul, Brasil.

- Hospital de Clínicas de Porto Alegre (HCPA), Serviço de Enfermagem Cardiovascular, Nefrologia e Imagem. Porto Alegre, Rio Grande do Sul, Brasil.

\section{ABSTRACT}

Objective: To develop and validate the content of an educational intervention on smoking cessation for Nursing professionals using a Blended Learning approach.

Method: A development and validation study by consensus of experts of the "Smoking Cessation" course for Nursing professionals on approaches to the smoking patient carried out in 2018. For refinement and validation of the final content, a convenience sample was made up of 12 professionals with expertise in the subject natter and an $80 \%$ consensus among the participants was considered. Results: The construction of the course involved the choice of subjects, production, and content validation. As a teaching strategy, Blended Learning was used, which has an interactive online stage and a face-to-face meeting to discuss concepts and exchange experiences.

Conclusion:The course using a Blended Learning method proved to be innovative, low-cost, and with great capacity for disseminating knowledge, being an important ally to permanent education in health.

Keywords: Tobacco use disorder. Education, nursing, continuing. Education, distance.

\section{RESUMO}

Objetivo: Desenvolver e validar o conteúdo de uma intervenção educativa sobre cessação do tabagismo aos profissionais de enfermagem utilizando abordagem híbrida.

Método: Estudo de desenvolvimento e validação por consenso de especialistas do curso "Cessação do Tabagismo" para profissionais de enfermagem sobre abordagens ao paciente tabagista conduzido no ano de 2018. Para refinamento e validação do conteúdo final contou-se com amostra de conveniência composta por 12 profissionais com expertise na temática e considerado 80\% de consenso entre os participantes.

Resultados: A construção do curso envolveu a escolha dos assuntos, produção e validação dos conteúdos. Como estratégia de ensino utilizou-se abordagem híbrida que possui etapa on-line interativa e um encontro presencial para discussão de conceitos e troca de experiências.

Conclusão: 0 curso utilizando método híbrido de ensino se mostrou inovador, de baixo custo e com grande capacidade de difusão do conhecimento, sendo um importante aliado à educação permanente em saúde.

Palavras-chave: Tabagismo. Educação continuada em enfermagem. Educação à distância.

\section{RESUMEN}

Objetivo: Desarrollar y validar el contenido de una intervención educativa sobre el abandono del hábito de fumar para profesionales de enfermería utilizando un enfoque híbrido.

Método: Estudio de desarrollo y validación por consenso de especialistas del curso "Dejar de fumar" para profesionales de enfermería sobre abordajes a pacientes fumadores realizado en 2018. Para refinar y validar el contenido final, se conformó una muestra de conveniencia de 12 profesionales con experiencia en el tema y se consideró consenso del $80 \%$ entre los participantes.

Resultados: La elaboración del curso implicó la elección de temas, producción y validación de contenido. Como estrategia de enseñanza, se utilizó un enfoque híbrido, que tiene una etapa interactiva online y un encuentro presencial para debatir conceptos e intercambiar experiencias.

Conclusión: El curso que utiliza el método de enseñanza híbrido demostró ser innovador, de bajo costo y con gran capacidad para difundir conocimiento, siendo un importante aliado para la educación permanente en salud.

Palabras clave: Tabaquismo. Educación continua em enfermería. Educación a distancia. 


\section{口INTRODUCTION}

Nursing Now is a campaign encouraged by the World Health Organization (WHO) to value the role of Nursing, offer better working conditions, and recognize its role of leadership. In order to achieve the objectives of this campaign, three targets were prioritized in Brazil, namely: investment in education, training of nurses to strengthen leadership, improvements in the working conditions of the Nursing professionals, and dissemination of effective and innovative Nursing practices based on scientific evidence ${ }^{(1)}$.

Among these targets, the development of innovative Nursing practices that are compatible with the current socio-economic scenario of the country stands out, as health assistance requires constant improvement and updates by means of different types of study and reflection. It is known that learning and teaching nowadays comprise the daily life of health organizations; however, within the assistance context, these practices face some difficulties, such as commuting of professionals, lack of adequate space for classes, and lack of motivation ${ }^{(2)}$.

Faced with this scenario, in-service education is emphasized, since it aims at reducing barriers and perceptions through training and support to Nursing care teams, justifying the importance of developing strategies to prepare these professionals how to approach smokers. In this regard, an international study evidenced that systematically implementing training in the Distance Learning (DL) format for nurses, Nursing technicians and assistants, in order to enable that they intervene in smoking cessation, can contribute to the improvement of Nursing assistance and to the reduction of the prevalence of smoking in the general population ${ }^{(3)}$.

Therefore, the elaboration of courses in the $\mathrm{DL}$ format enables flexibility and autonomy for the workers to perform the proposed activities and meets knowledge needs, in addition to including a higher number of people to be trained ${ }^{(4-6)}$. In this perspective, "Blended Learning", known in Brazil as "Abordagem Hibrida", which consists of offering learning activities including face-to-face moments and technologies, is conquering a prominent space and has been described as an innovative initiative in the education of health professionals ${ }^{(7)}$.

However, there is lack of research studies in the literature suggesting the development and assessment of using Blended Learning with Nursing professionals in relation to the assistance to hospitalized smokers. Therefore, the present study had the following guiding question to contemplate this lack of knowledge:"How can a course content be created and organized using Blended Learning to train Nursing teams in the approach to the smoker in order to promote smoking cessation?"
Accordingly, this study aimed at developing and assessing the content of an educative intervention about smoking cessation for Nursing professionals using Blended Learning. It is believed that, by disseminating this strategy, it is possible to spread this practice and motivate Nursing professionals to implement assistance including education actions in health directed to smoking cessation along with the hospitalized patients.

\section{$\square$ METHOD}

This is a study of development and validation of content by a consensus of experts of the course entitled "Smoking Cessation". Consensus validation enabled to reach collective opinion or agreement among experts on a specific theme, being used in the area of Nursing as it contributes to standardize the practices performed by the professionals ${ }^{(8-9)}$.

The study was carried out from January to December 2018 in a large university hospital in the South of Brazil. The course content preparation had the participation of Nursing and Medicine professors, nurses, physicians, and a Nursing student, who gathered by their interest and affinity in studying this theme. Monthly meetings were developed, totaling 11 60-minute meetings, which had as agenda defining and selecting content based on the guidelines validated by the Ministry of Health on approaches to smokers, literature review, and experiences of professionals who are experts on the theme. The importance of courses using Blended Learning with online and face-to-face stages was established as a learning strategy by the group. It was also defined in these meetings that the target audience responsible for carrying out the course would be Nursing team's collaborators working in the institution and the academic community of the Nursing School of a Federal University in the South of Brazil that had individual access to the hospital's Virtual Learning Environment (VLE) upon the creation of a user and a personal password.

After the content and pedagogical strategy definitions, the material was adapted and developed by an instructional designer to make the VLE available. At this stage, language adaptations, inclusion of illustrations, creation of the avatar, and construction of exclusive and interactive layout were also developed ${ }^{(8-11)}$. The creative process had meetings and discussions between researchers and the institution's pedagogical team.

Subsequently, the content of the educational material was refined and validated ${ }^{(8)}$ by a convenience sampling composed of 12 professionals specialized in the field, including members of the People Management Coordination, work safety engineers and technicians, specialists in the area of education, and members of the institution's Smoking 
Control Commission. This commission is multidisciplinary and aims at promoting strategies to fight against smoking and give support to those who want to quit. An $80 \%$ consensus by the experts was considered to define and validate the content.

Once the contents and course structure were defined, a pilot test was carried out with 10 Nursing professionals, and the inclusion criterion consisted in providing assistance to smokers. In this situation, the nurses and nursing technicians attended the course and could verify the layout acceptability, understanding, and presentation, and then contribute with suggestions to its refining.

Validation and the pilot test occurred through the filling of an instrument via Google Forms ${ }^{\varpi}$, which contained the following information: "By answering, you agree with the use of the data in this research. Anonymity shall be guaranteed and your participation will enable course enhancement about the approach to the smoker". This research is related to the project entitled "Factors that contribute to smoking cessation in a hospital university" approved by the institution's Research Ethics Committee (CAAE 64475916700005327).

\section{RESULTS}

The result of this study had the course as its product, using Blended Learning in teaching, which is entitled "Smoking cessation" and consists of two stages, the first is online, a prerequisite for the second face-to-face stage. The first stage was implemented in the institutional VLE, covering the following themes: What smoking is, related diseases, chemical and behavioral dependence; Importance of the decision in the process to quit smoking; What to approach at admission, during hospitalization, at discharge, and during the patient's post-discharge; Stages of change; Strategies to quit smoking; Benefits of quitting smoking; Use of medications; Follow-up of smokers and the Institution's Smoking Control Plan.

The contents developed over the online stage are presented by means of an exclusive visual identity with an avatar named Luci with the objective to turn the course's layout and labels more interactive and attractive, since it adds personality by interacting and talking with the participant, with the ability to awaken interest and ease learning. The course audiovisual resources have 57 colorful slides, in addition to a three-minute video. Figure 1 presents how the course is structured in the Institutional VLE when the students start it.
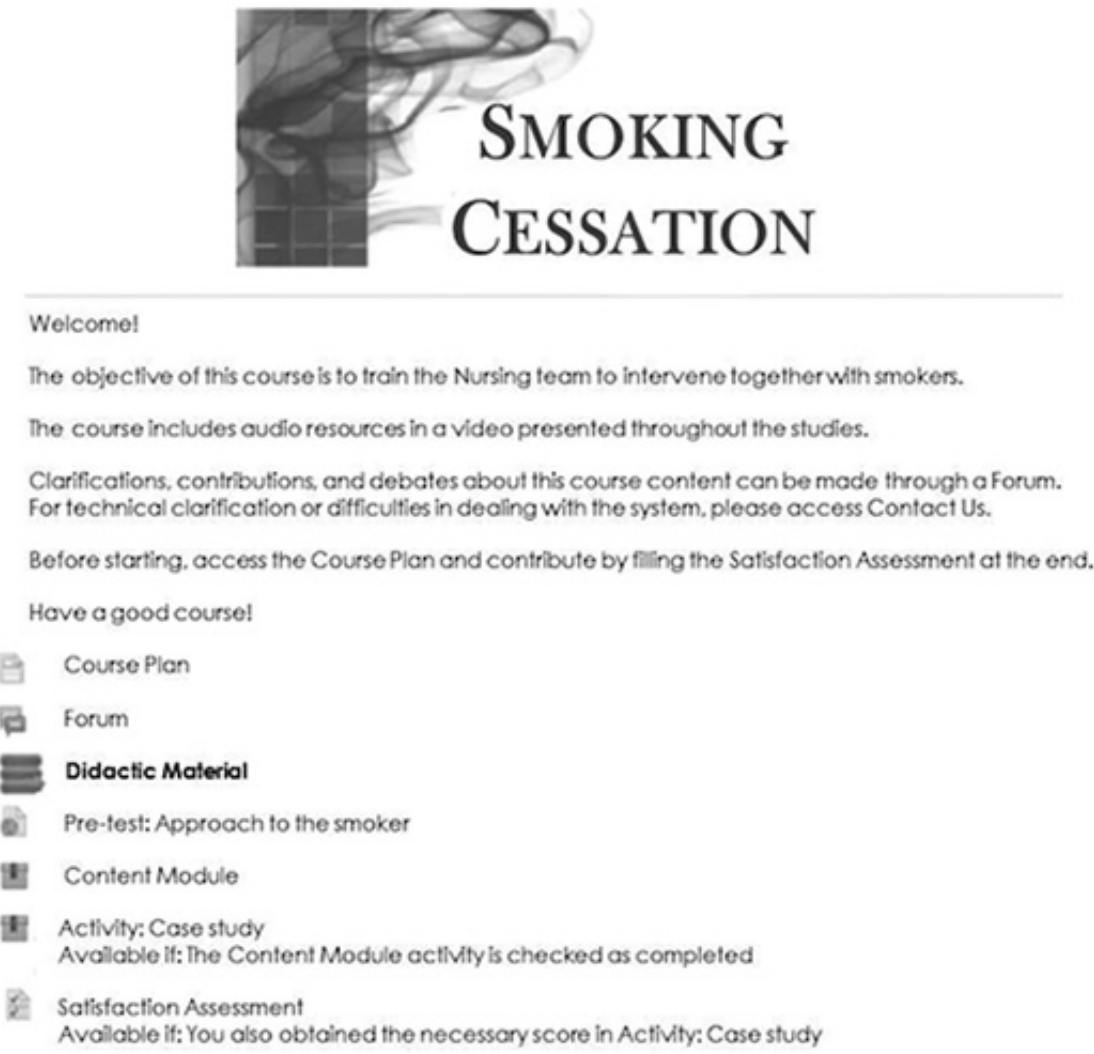

Figure 1 - Layout of the initial presentation of the course in Moodle 
For good course performance at the online stage, one hour of dedication is recommended for the participants. As a learning strategy, the avatar drives the content, interacting and presenting the themes approached interactively with animations, videos, tables, graphs, and the performance of a case study about the theme developed. In Figure 2, some examples of the theoretical material screens developed are presented.

The participants will be able to self-assess themselves and, if necessary, search supplements for their learning in the bibliography recommended. The professional must carry out a content reading and achieve a minimum passing grade of 65 points in the case study activity to be approved at this stage of the course. It is highlighted that it is possible to reassess the material and redo the study case as often as needed for approval (Figure 3).

At the end of the activities, voluntary participation is suggested in an interactive forum, the VLE, to provide the professionals with an exchange of experiences regarding assistance to smokers.

After being approved at the online stage, the Nursing professionals are invited to participate in a face-to-face meeting, the second moment of the Blended Learning proposed. It aims at listening to the participants' reports about their daily routine, how they are approaching this theme in the clinical practice, their difficulties, and doubts about the assistance provided to smokers, revisiting some essential concepts to support interventions to quit smoking and close discussions about the theme. The participants can see the dates of the meetings, scheduling the best day for their participation in the VLE (Figure 4).

Face-to-face meetings are performed on a monthly basis in an equipped classroom available in the Institution. During the activity, support materials are delivered to support the approaches, such as educational brochures, a book on smoking cessation with testimonies of people who managed to quit smoking, and scales to assess patients' dependence to nicotine and level of motivation for smoking cessation. These meetings last one hour and thirty minutes and are conducted by the project researchers and by the nurse of the Institution's smoking cessation outpatient sector.

The course on smoking cessation developed and validated by means of this study used Blended Learning as a methodological proposal to emphasize the importance of early identifying the smoker, i.e., at the time of hospitalization, and learning ways to them through scientifically recognized approaches. The actions of the Institution's Smoking Control

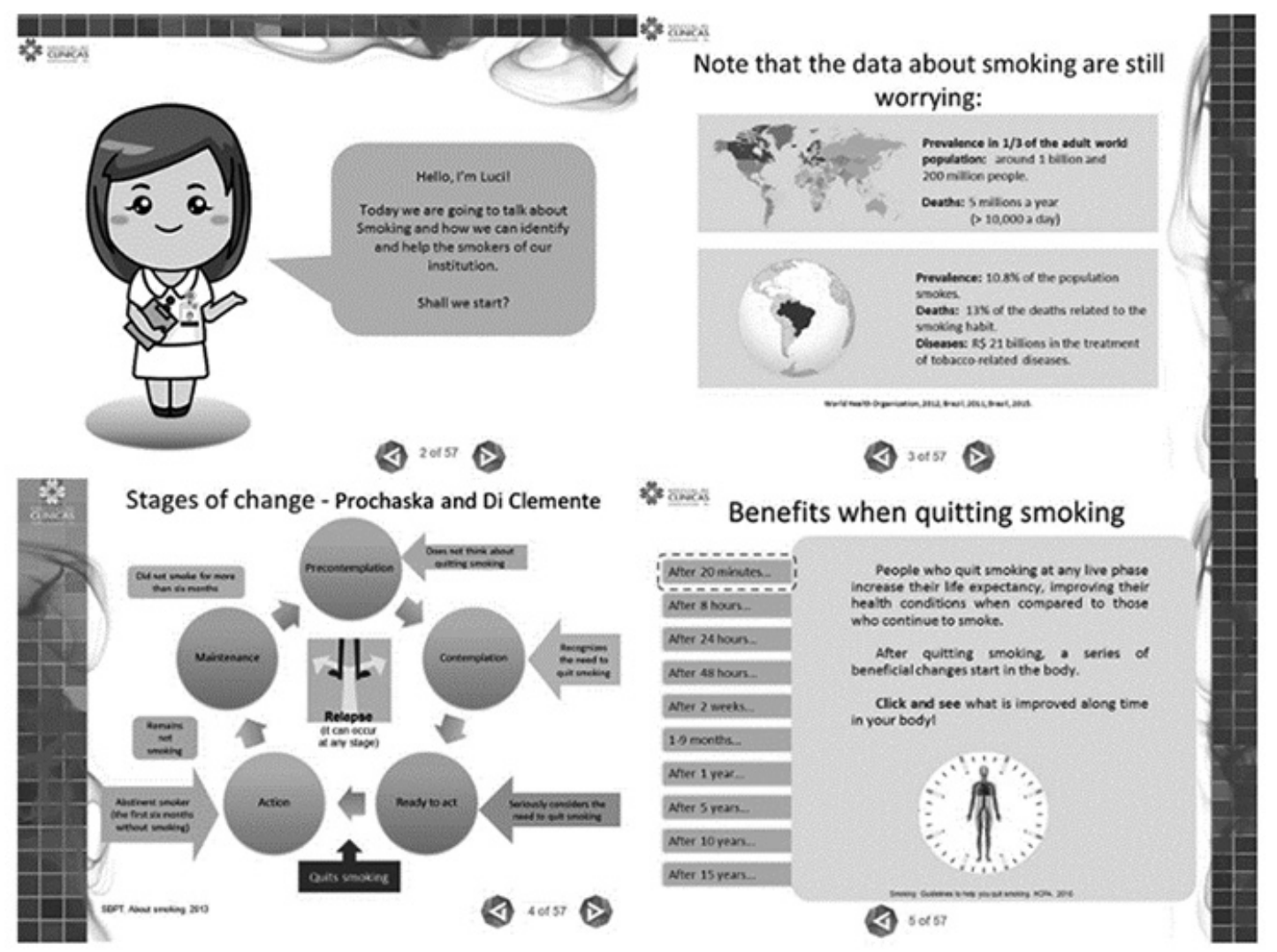

Figure $\mathbf{2}$ - Screens of the interactive theoretical model Source: Authors, 2018. 


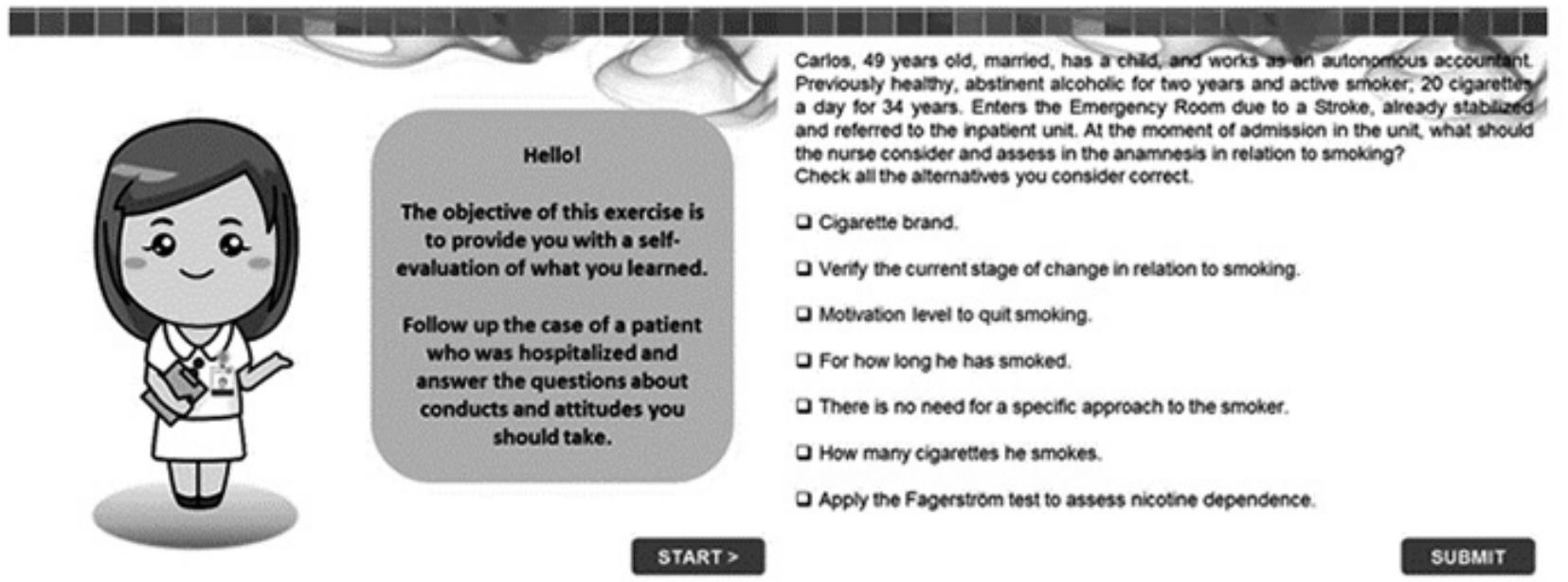

Figure $\mathbf{3}$ - Layout of the case study proposed for evaluation Source: Authors, 2018.

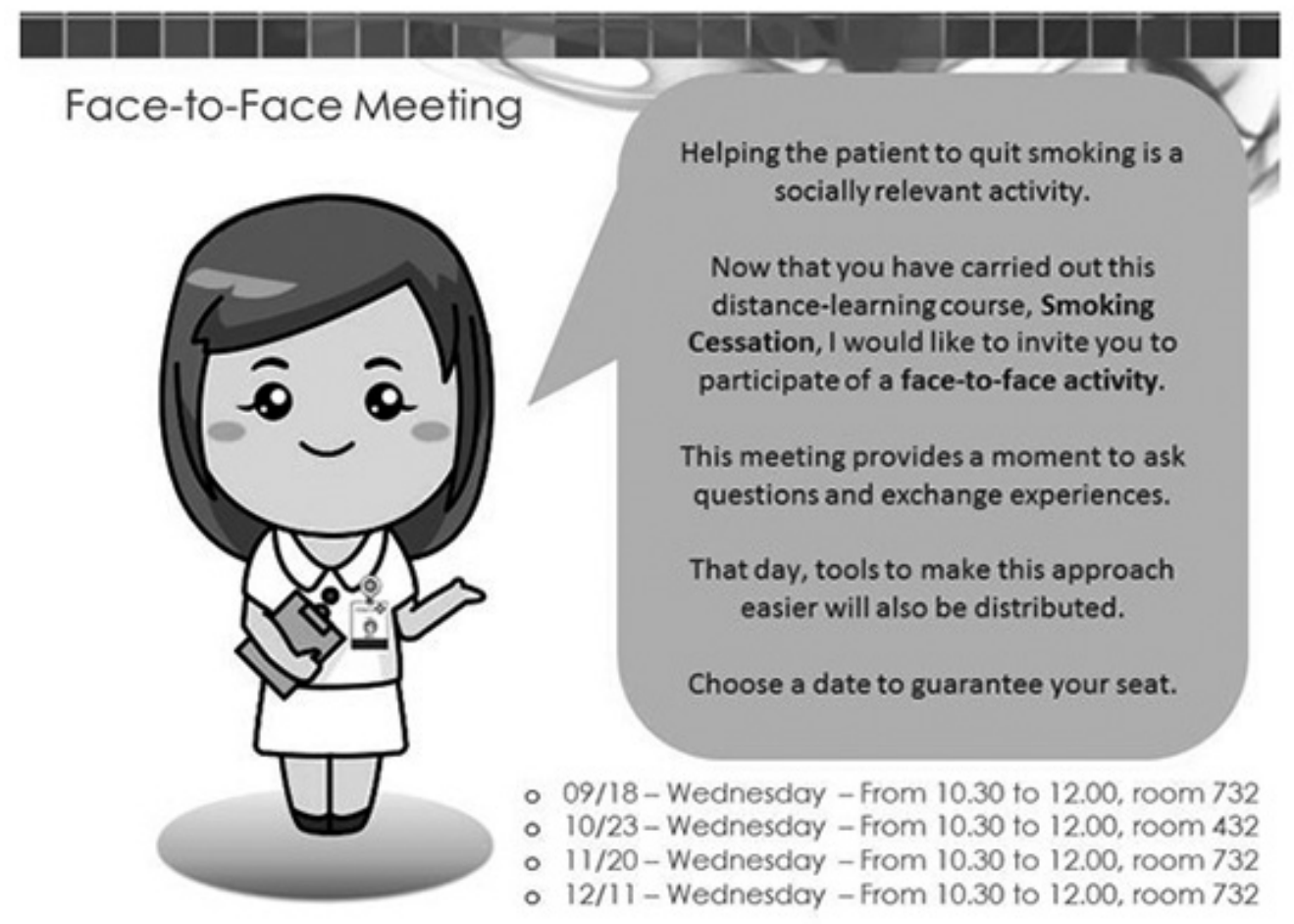

Figure 4 - Scheduling layout to participate in the face-to-face activity

Source: Authors, 2018.

Commission to promote patients, visitors, and professionals' health regarding tobacco are also published, as well as advertising campaigns about cigarette harms and strategies of approaches for cessation.

Additionally, the course aimed at favoring that the Nursing professionals can perform effective approaches, promote smoking cessation, starting with an assessment at admission, including smoking issues during anamnesis followed by instructions during hospitalization so that the patients succeed in maintaining abstinence even after hospital discharge. Its purpose is to qualify the Nursing team work in the assistance provided to this population. 


\section{DISCUSSION}

The elaboration and validation of an educational intervention using Blended Learning as a methodological strategy reached a higher number of professionals through distance learning combined with a face-to-face moment, enabling problematization among the Nursing professionals about the theme under study. Associated to that, after the National Policy of Continuing Education in Health enacted in 2004, several proposals for continuing education of Nursing professionals have emerged in health institutions, containing discussion about work processes and encouraging significant learning. However, there is still a gap in the literature about research studies suggesting educational interventions on an approach to the hospitalized smoker directed to Nursing professionals. Therefore, it is believed that this proposal can impact on assistance qualification.

In this perspective, a number of research studies have indicated the importance of blended educational interventions with the online stage complemented by face-to-face axes, justifying that these moments can impact more on the change of the assistance practices as they promote dialog and exchange of experiences, making the learning process more critic and rational(13-14).

A survey carried out in the United States with the objective of assessing the effect of an educational intervention using Blended Learning on the application of the Screening, Brief, Intervention, Referral to Treatment (SBIRT) model to identify, reduce, and prevent tobacco, alcohol, and other drugs use/abuse evidenced that the participants would recommend the course to others, highlighting the importance of the face-to-face axis to the closure of ideas and

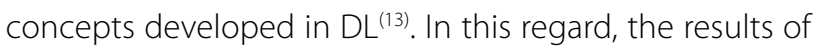
another international research study with nurses who took online training on assistance to hospitalized smokers aimed at smoking cessation evidenced that, after attending the course, there was a significant increase in the number of professionals who referred smokers for treatment to quit smoking. Additionally, the authors of the aforementioned study suggested that the inclusion of face-to-face meetings to complement the online training could cause a more significant impact, as well as permanently changing the assistance practices ${ }^{(14)}$.

Considering the importance of the face-to-face meeting as a guide for dialog and exchange of experience among the Nursing professionals on the theme in question, this study that aimed at developing and validating a course using Blended Learning had as primary motivation including the need for a face-to-face moment in which it was possible to consolidate the content developed during the online stage.
In addition, the face-to-face meeting also raised awareness among the participants about their importance as educators/agents of transformation concerning this severe public health problem.

It is known that smoking is associated with an increase in the risk of avoidable hospitalizations due to chronic diseases in older adults, such as diabetes, chronic obstructive pulmonary disease, and heart failure ${ }^{(15)}$. In this context, the role of nurses stands out, who have competences to develop and implement strategies to assist smokers in the smoking cessation process, whether in outpatient sectors, hospitals, or at the primary health care network.

In the study Institution, in the face of a hospitalization, nurses systematically collected anamnesis and administered a physical examination to later diagnose, plan, and implement interventions. At this moment, it is of utmost importance that the professional identifies risk behaviors such as the smoking habit to establish and propose specific care actions, as well as to permanently perform educational actions in health directed to the change of behavior in this patient based on the guidelines validated ${ }^{(10)}$.

It is important to highlight that the hospitalization of a smoker is an important moment of reflection in which the patient is usually more sensitive to the adoption of healthy behaviors and receptive to the counseling of the assistance team about smoking cessation, as the reason for hospitalization can be a consequence of this practice ${ }^{(11)}$. However, a research study carried out in Hong Kong verified that more than half of the nurses participating in that study believed they lacked the knowledge and abilities required to help patients quit smoking, are not confident to assume this role, and are not familiarized with all the supportive services available for smoking cessation ${ }^{(16)}$.

Therefore, considering the proposal of the Nursing Now campaign, it is understood that spreading effective and innovative teaching practices can contribute for Nursing to assist in the fight against a severe public health problem, which is smoking, as well as provide higher visibility to initiatives consistent with the current socio-economic context of the country so that they can be reapplied in other scenarios and institutions.

Regarding the development of the theoretical content that would be addressed, the previous knowledge of the Nursing professionals and the practices identified in the daily routine regarding the smoking habit were considered because a recent study identified that few interventions were performed with smokers in this scenario ${ }^{(17)}$.

These initiatives meet the National Policy of Continuing Education in Health guidelines, which bring continuing education as a learning proposal in work, where learning 
and teaching are part of the organizations'routine ${ }^{(18)}$. Developing contents with problematization and considering the previous knowledge of the professionals enables that, along the course, they encounter situations of their work routine, which makes the learning process more significant. Therefore, the problematizing pedagogies collaborate with teamwork in health care teams, improving care ${ }^{(19)}$. For improving the course, within the multidisciplinary team that built it, it was imperative to include experts in the education in health area, who have pedagogical knowledge in order to define the best methods and resources required to attain the educational objectives established.

One of the methodological strategies consists in the use of an online and interactive forum that enables exchange of experiences through debates and clarification of questions, which promotes an expansion of scientific knowledge among the participants involved and meets the goals of the Nursing Now international campaign, which aims at spreading effective practices to qualify the performance of Nursing professionals in their approaches to smokers ${ }^{(1,20)}$.

As knowledge is renewed, new strategies may emerge and, considering that smoking is an important public health problem and that the percentage of smokers is high, this initiative should continue. It is also reasserted that this a low-cost and easy-access method, and that it has a capacity for spreading knowledge; essential aspects to be taken into consideration given the current socio-economic scenario.

\section{FINAL CONSIDERATIONS}

The development and validation of the course on smoking cessation using Blended Learning as methodological proposal have been an important tool, which enabled the training and sensitization of the Nursing team regarding this theme.

It is believed that the implementation of educational actions directed to this group of professionals, aiming at smoking cessation, can qualify the assistance provided to hospitalized smokers, as it trains the Nursing team to offer more specific care to these individuals. It is understood that sharing good practices in Nursing developed through scientific evidence like this can contribute to the promotion of healthy behaviors.

A limitation of this study is the fact that the impact of this educational action on the assistance provided to hospitalized smokers has not been assessed yet. However, its success enabled that it was offered again in 2020 to Nursing professionals. Therefore, it is expected that more smokers can be benefited from qualified approaches, so that there is a significant reduction in the prevalence rates of smokers and an increase in the quality of life of the general population.

\section{REFERENCES}

1. Cassiani SHB, Lira Neto JCG. Nursing perspectives and the "Nursing Now" campaign. Rev Bras Enferm. 2018;71(5):2487-8. doi: https://doi. org/10.1590/0034-7167.2018710501

2. Monteiro AKC, Monteiro AKC, Andrade EMLR, Luz MHBA, Cavalcanti PAL. Distance continuing education on prevention of pressure ulcer. Rev enferm UERJ. 2016;24(1):e5733. doi: https://doi.org/10.12957/reuerj.2016.5733

3. Králíková E, Felbrová V, Kulovaná S, Malá K, Nohavová I, Roubíčková E, et al. Nurses' attitudes toward intervening with smokers: their knowledge, opinion and e-learning impact. Cent Eur J Public Health. 2016;24(4):272-5. doi: https:// doi.org/10.21101/cejph.a4652

4. Covalsky CM, Mota JC. Limites e possibilidades de estudantes na Educação a Distância (EAD). Rev Unifebe. 2016 [cited 2020 Mar 26];18(1):75-87. Available from: https://periodicos.unifebe.edu.br/index.php/revistaeletronicadaunifebe/ article/view/399/216

5. Pereira EBF, Modesto BCM, Valença MP, Silva JuniorWS, Souza CFQ. Development and assessment of a virtual learning environment for training in malignant hyperthermia. Rev SOBECC. 2017;22(4):180-7. doi: https://doi.org/10.5327/ 21414-4425201700040002

6. Silva NA, Santos AMG, Cortez EA, Cordeiro BC. Limites e possibilidades do ensino a distância (EaD) na educação permanente em saúde: revisão integrativa. Cienc Saúde Coletiva. 2015;20(4):1099-107. doi: https://doi. org/10.1590/1413-81232015204.17832013

7. Mohanna K. The use of elearning in medical education. Postgrad Med J. 2007;83(978):211. doi: https://doi.org./10.1136/pgmj.2007.058610

8. Oliveira MC, Lucena AF, Echer IC. Neurological sequelae: preparation of a guidance manual for health care. Rev Enferm UFPE on line. 2014 [cited 2020 mar 16];8(6):1597-603. Available from: https://periodicos.ufpe.br/revistas/ revistaenfermagem/article/view/9850/10062

9. Pinheiro JQ, Farias TM, Abe-Lima JY. Painel de especialistas e estratégia multimétodos: reflexões, exemplos, perspectivas. Psico. 2013 [cited 2020 Jun 14];44(2):184-92. Available from: http://revistaseletronicas.pucrs.br/ojs/index. php/revistapsico/article/view/11216/9635

10. Ministério da Saúde (BR). Portaria no 761, de 21 de junho de 2016. Valida as orientações técnicas do tratamento do tabagismo constantes no Protocolo Clínico e Diretrizes Terapêuticas - Dependência à Nicotina. Diário Oficial da União. 2016 jun 22 [cited 2020 Jun 10];153(118 Seção 1):68-9. Available from: https://www.inca.gov.br/sites/ufu.sti.inca.local/files//media/document// portaria-n-761-de-21-de-junho-de-2016.pdf

11. Vogiatzis I, Pantzartzidou A, Pittas S, Papavasiliou E. Smoking cessation advisory intervention in patients with cardiovascular disease. Med Arch. 2017;71(2):12831. doi: https://doi.org/10.5455/medarhh.2017.71.128-131

12. FloresGE,Oliveira DLL,ZoccheDAA. Educação permanenten n contexto hospitalar: a experiência que ressignifica o cuidado de enfermagem. Trab Educ Saúde. 2016;14(2):487-504. doi: https://doi.org/10.1590/1981-7746-sip00118

13. Acquavita SP, Loon RAV, Smith R, Brehm B, Diers T, Kim KK, et al. The SBIRT Interprofessional Curriculum and Field Model. J Soc Work Pract Addict. 2019;19(1-2):10-25. doi: https://doi.org/10.1080/1533256X.2019.1589883

14. Sarna L, Bialous SA, Wells M, Brook J. Impact of a webcast on nurses' delivery of tobacco dependence treatment. J Clin Nurs. 2017;27(1-2):e91-99. doi: https:// doi.org/10.1111/jocn. 13875

15. Tran B, Falster MO, Douglas K, Blyth F, Jorm LR. Smoking and potentially preventable hospitalisation: the benefit of smoking cessation in older ages. Drug Alcohol Depend. 2015;150:85-91. doi: https://doi.org/10.1016/j.drugalcdep.2015.02.028 
16. Mak YW, Loke AY, Wong FKY. Nursing intervention practices for smoking cessation: a large survey in Hong Kong. Int J Environ Res Public Health. 2018;15(5):1046-60. doi: https://doi.org/10.3390/ijerph15051046

17. Boni FG, Osmarin VM, Juchem BC, Mantovani VM, Echer IC. Cessação do tabagismo: ações da equipe de saúde na hospitalização. Rev Recien. 2020;10(31):13-23. doi: https://doi.org/10.24276/rrecien2020.10.31.13-23

18. Ministério da Saúde (BR). Portaria no 198, de 13 de fevereiro de 2004. Institui a Política Nacional de Educação Permanente em Saúde como estratégia do Sistema Único de Saúde para formação e do desenvolvimento de trabalhadores para 0 setor e dá outras providências. Diário Oficial da União. 2004 fev 16 [cited 2020 Apr 10];141(32 Seção 1):37-41. Available from: https://pesquisa.in.gov.br/imprensa/jsp/visualiza/index. jsp?data $=16 / 02 / 2004 \&$ jornal $=1 \&$ pagina $=37 \&$ totalArquivos $=72$

\section{- Authorship contribution:}

Conceptualization: Fernanda Guarilha Boni, Lyana Duarte Borba da Silva, Jamila Grigolo, Solange Klockner Boaz and Isabel Cristina Echer.

Data curation: Fernanda Guarilha Boni, Lyana Duarte Borba da Silva, Jamila Grigolo, Solange Klockner Boaz and Isabel Cristina Echer.

Formal analysis: Fernanda Guarilha Boni and Isabel Cristina Echer.

Investigation: Fernanda Guarilha Boni and Isabel Cristina Echer.

Methodology: Fernanda Guarilha Boni and Isabel Cristina Echer.

Project management: Isabel Cristina Echer.

Software: Lyana Duarte Borba da Silva and Jamila Grigolo. Supervision: Isabel Cristina Echer.

Validation: Fernanda Guarilha Boni, Lyana Duarte Borba da Silva, Jamila Grigolo, Solange Klockner Boaz, Ana Luísa Petersen Cogo and Isabel Cristina Echer.

Visualization: Fernanda Guarilha Boni, Lyana Duarte Borba da Silva, Jamila Grigolo, Solange Klockner Boaz, Ana Luísa Petersen Cogo and Isabel Cristina Echer.

Writing - Original draft: Fernanda Guarilha Boni, Lyana Duarte Borba da Silva, Jamila Grigolo, Solange Klockner Boaz, Ana Luísa Petersen Cogo and Isabel Cristina Echer. Writing - Review and editing: Fernanda Guarilha Boni, Lyana Duarte Borba da Silva, Jamila Grigolo, Solange Klockner Boaz, Ana Luísa Petersen Cogo and Isabel Cristina Echer.

\section{- Corresponding author:}

Fernanda Guarilha Boni

E-mail: fernandagboni@gmail.com

Received: 06.17.2020

Approved: 10.23 .2020
19. Souza RMP, Costa PP. Educação Permanente em Saúde na formação da Rede Brasileira de Escolas de Saúde Pública. Saúde Debate. 2019;43(spe 1):116-26. doi: https://doi.org/10.1590/0103-11042019s110

20. Frutuoso IS, Doimo TMA, Marqui R, Contrin LM, Ribeiro RCHM, Werneck AL. Creation of a virtual learning environment in intensive care. Rev Enferm UFPE on line. 2019 [cited 2020 Jun 05];13(5):1278-87. Available from: https:// periodicos.ufpe.br/revistas/revistaenfermagem/article/view/238907/32225

\section{Acknowledgments:}

Coordination of Improvement of Higher Level Personnel (Coordenação de Aperfeiçoamento de Pessoal de Nivel Superior, (APES).

\section{Associate editor:}

Dagmar Elaine Kaiser

\section{Editor-in-chief:}

Maria da Graça Oliveira Crossetti 